\title{
Teaching Business Ethics to Nigerian Senior Managers: Meeting the 'How' Expectations
}

\author{
Kemi Ogunyemi \\ Lagos Business School, Lagos, Nigeria \\ kogunyemi@lbs.edu.ng
}

\section{Doi:10.5901/mjss.2013.v4n9p453}

\begin{abstract}
One task of ethics education is to enhance the ethical reasoning capabilities of future business leaders so that they may act rightly at ethical decision 'crossroads' (Jones, 2005, MacLagan, 2003). To achieve this, both educator and students should have a meeting of minds as to the meaning and relevance of business ethics. Simultaneously, guidance regarding the practical details of 'how' to act in specific situations may be an important component of ethics education in emerging economies where intentions are easily frustrated by an overwhelming consciousness of operating in a corrupt environment. A group of Nigerian senior managers was challenged to generate a strategy to institute an ethical culture in an organization with a history of corruption. They did this through a simulation activity based on a fictitious company. In the process, they experienced the fulfilment of an important part of their expectations from the business ethics sessions they were attending.
\end{abstract}

Keywords: Business ethics education; managers; expectations; ethical transformation; emerging economies

\section{Introduction}

In giving a class of business ethics in Nigeria, a country with a high index of corruption, one at times experiences a great variety of attitudes from the audience. These attitudes could be summarized into three types $-a)$ those who have no faith in the classes and therefore have little interest in the discussions; b) those who are keenly interested in knowing what constitutes ethical business behaviour and how to effect the changes that practicing it would entail while remaining profitable; and c) those who are already convinced that it is worthwhile and important to act ethically and do not derive additional conviction from the classes. Those in groups a) and c) are usually few, while those in group b) are the majority of the students. In general, however, many of the class debates are about the how questions - about the feasibility and sustainability of running a business ethically in a market where the competition is ready to engage in corrupt practices if you are not, and how to do it.

This means that even if and when those in the b) group and others who move from the a) and c) groups to join them have greater clarity at the end of the course about what business ethics is and agree on how important it is, most of them may still end up unwilling to take or unable to implement the difficult decisions to change how business has always been done in their own company. As Jewe (2008) points out in concluding his paper, attitudes to ethics may perhaps not change, but even when there is already a prevalent positive attitude, other questions remain a challenge for the ethics course - such as increasing awareness of the issues and empowering students to make the ethical decisions they wish to make. Lau (2010) confirmed this when he tested the effect of business education on awareness and moral reasoning. The 'how' to do it challenge however goes beyond knowing what to do and being able to reason it out intellectually to include a practical component that may be useful in cases where it is easy to tend to inertia or reluctance to change the status quo. In Nigeria for example, a major part of the problem of implementing the practice of ethics is an abiding disillusionment regarding the possibility of surviving against the current in a country where unethical practice is becoming almost accepted as the norm. Such disillusionment promotes inertia and needs to be overcome by helping people to take action.

Hence, even though there is a tendency to obtain a consensus from business ethics students that in the long run running a business ethically could be profitable - reasons include the reputational advantages - a merely theoretical or abstract approach to imparting knowledge would almost surely remain inadequate to prompt behaviour change. The case study approach to teaching goes farther than that, given its practical orientation; yet, it is still possible for the students to engage in analysing and resolving the problems facing case study protagonists at a safe distance, without truly personalizing the values they recommend in the process. To overcome disillusionment and to commit to devising ways to establish cultures of integrity, that personal involvement and commitment is needed. It cannot be effectively imparted 
through attending classes modelled around understanding the teacher's convictions. A channel to evoke and bring to the surface the students' deepest convictions is required, in such a way that they will own the process of change and be ready to deploy their intellectual resources to achieve it.

This paper reports a case-study based exercise carried out at the Lagos Business School in business ethics sessions which attempted with some degree of success to close the distance by engaging the students personally in answering their 'what' and 'how' questions so that they would take ownership of the solutions generated and come closer to applying them in their own organizations. As posited by Heller and Heller (2011), students of business ethics are precisely meant to engage in learning that leads to its application in their business dealings as agents of the company. Any approach to the teaching of ethics that could contribute to achieving this end would thus be worth trying out. It would be interesting in future to base this type of action learning exercise on a real ethical dilemma facing one of the companies of those in the classroom and have them diagnose the problem and propose the solutions thereto. It would in this way also constitute some form of service learning (Razaki and Collier, 2011).

\section{Methodology}

The exercise was carried out in a class of senior management programme participants in the Lagos Business School. There were thirty (30) of them in the class and they were from the different industries.

A minute paper during the third session elicited their expectations from the business ethics class. This had the effect of making them articulate their own positions with regard to business ethics education as well as commit to getting something from the sessions. They were given the option of handing in their submissions in anonymity or making themselves known by signing the papers in order to be available for further discussions of their answers. The anonymity option was expected to exclude any incidence of social desirability bias in the responses, despite the fact that the class had already shown itself as ordinarily honest and outspoken in giving their opinions in the previous discussions. Four people took the option of remaining anonymous. The expectations are included as an appendix to this paper.

After they had been on the programme for about three weeks and had received seven sessions on Business Ethics, the exercise of simulating the answer to the most recurring of their 'how' questions was carried out. The exercise consisted of challenging them to change the culture of a company to an ethical one. They were divided into five groups of six persons each and each group had to tackle the same scenario - a new CEO whose company had reneged on its original intent to be a company with a reputation for integrity was facing the challenge of restoring the culture and making a pitch to a client in a few days time; the client was already used to receiving questionable payments from the company in the past.

The purpose of the exercise was to have the students themselves create the solution to the problem; to have them strategize for change and overcome the inertia that usually tends to stop them from taking the steps to make a difference. In this way, rather than have the expectation that faculty would come up with a blueprint for how to restore an ethical climate, they would experience doing it themselves and would emerge more convinced that the solution was practicable, coming as it had done from themselves and their peers. Each group had ten minutes in which to discuss their plans and then had to elect a CEO to make a presentation to the class. The CEO had seven minutes to present the transformation agenda, and other members of the group had to respond to at least two questions from the audience - the rest of the class.

\section{Results}

The five groups embraced the challenge with enthusiasm and worked hard to come up with a strategy that would work. In the process, they lost all cynicism about the viability of an ethical company. Indeed some of the groups became quite critical towards other groups whom they saw as standing on the borderline between ethical and unethical behaviour. In the whole process, they listened and argued and defended positions which they might have received with a jaundiced view if the faculty had canvassed them. Many valuable insights emerged. Each group addressed the issues both in the short term (the client expecting a presentation in a few days time) and in the long term (an overhauling of the company's values). Eventually, it was clear that all the proposed options were complementary. They ended up with a solid proposal about the way to successfully attain the set goal of ethical transformation.

Table 1 below is a synthesis of the ethical culture restoration (ECR) blueprint that they came up with. Some of the stages would proceed simultaneously. 
Table 1: ECR Blueprint

\begin{tabular}{|c|c|c|c|c|}
\hline Stage 1 & Stage 2 & Stage 3 & Stage 4 & Stage 5 \\
\hline New Vision/Mission & $\begin{array}{c}\text { Internal } \\
\text { Communication }\end{array}$ & $\begin{array}{c}\text { Systems Audit and } \\
\text { Revamp }\end{array}$ & $\begin{array}{c}\text { External } \\
\text { Communication }\end{array}$ & Consolidation \\
\hline $\begin{array}{l}\text { Revise what the } \\
\text { value offering is }\end{array}$ & $\begin{array}{c}\text { Talk to top } \\
\text { management }\end{array}$ & $\begin{array}{l}\text { Improve product and } \\
\text { service quality }\end{array}$ & $\begin{array}{l}\text { Reach out to new and } \\
\text { existing clients }\end{array}$ & Engage staff more \\
\hline Total reorientation & Talk to all staff & $\begin{array}{l}\text { Revise processes and } \\
\text { policies to increase } \\
\text { controls }\end{array}$ & Rebrand & Brand \\
\hline $\begin{array}{l}\text { Be ready to lose } \\
\text { some business }\end{array}$ & $\begin{array}{l}\text { Gradually weed } \\
\text { out 'bad eggs' }\end{array}$ & $\begin{array}{c}\text { Check the reward } \\
\text { system }\end{array}$ & $\begin{array}{l}\text { Prospect new and } \\
\text { former clients }\end{array}$ & $\begin{array}{l}\text { Clarify details and tie } \\
\text { loose ends }\end{array}$ \\
\hline
\end{tabular}

\section{Discussion}

The results of the exercise confirmed that if even disillusioned Nigerian managers are challenged in the right way, they themselves hold the solutions to the problems of corruption in the country and can begin to fix them. It also illustrated the various ways in which the issues should be tackled. While some of the ideas seemed to draw on the past seven ethics sessions, many were clearly results of the students themselves giving thorough attention to the issues and wanting to successfully achieve an ethical transformation.

The idea behind crafting a new vision and mission would be to signal the change first internally and then externally. In the process, the company would rearticulate or restate its core values and remind everyone of the need for these to permeate the whole company. This would begin by engaging the top management of the company and then involving also all other staff in reshaping the character of the company to embrace the highest standards of integrity and to project that in its new profile and image. It would also entail an emphasis on presenting a value proposition that clients would find it very difficult to ignore - in the words of the students, positioning as the best and cleverest in the industry. This would reduce and perhaps eventually wipe out the tendency to reliance on handouts to win bids.

They also advocated a zero tolerance orientation towards corruption and suggested that those among staff who refused to embrace the new company should be eased out of the system gradually, say over six months. The need for avoiding an immediate and radical action to dismiss them all at once was justified by the need to first get to know the business thoroughly and reduce dependence on these staff, especially when they hold key positions. In this way the students demonstrated that they were being as close to reality as possible in their considerations and conscious of not advocating actions that could harm the company without due reflection on the best approach to each. At the same time, this would give enough of a chance for second thoughts to those who might wish to change their minds and accept the company's new character.

Linked to the discussion of zero tolerance was a discussion of the different euphemisms for bribes and corrupt payment and this common awareness would make it easier to identify and to get rid of it in all its forms - public relations (PR), grease, Roger, brown envelopes, 'happy weekend', business acquisition fees, facilitation, 'egunje', payout, graft, 'riba', 'alubosa' (onions to sweeten the stew), etc. Some minutes were devoted to a discussion of the need to be careful with "corporate gifts" which may or may not constitute bribes depending on their size, the industry custom and real possibility of their influencing an official - private or public - to act in favour of the company and contrary to good and fair judgement. With regard to PR, one of the contributions drew attention to the anomaly of its nomenclature - giving the name 'public' to something that is inherently always a private exchange of money that is unaccounted for. It was interesting to note that for some of its forms, making it truly public could probably neutralize its negativity or at the very least highlight its absurdity, as would happen if what was being given to one agent of the company as PR behind closed doors could be instead disclosed to every staff of both companies and to competitors.

As part of the internal communication, the need to have clear processes and policies was emphasized. For example, in a below-the-line (BTL) advertising company, there could be a need to specify the rate cards as much as possible, going into the details of how much should be paid to a Master of Ceremonies, to a clown, to a bouncer, etc. This would increase the level of transparency in these transactions. Also, in any company, a clear gift policy would reduce confusion as to what was permissible to give out or to receive, if anything was.

Internal communication would also mean incentivising and rewarding good behaviour at the same time as instituting tighter controls in the system. For example, there was a suggestion that staff could be rewarded for deals sealed at the lowest cost to the company. While the idea sounds attractive in itself, it would need to be explored further to 
determine its practicability and usefulness within the scope of the exercise under consideration.

As stated above, part of the scenario in the case study on which the exercise was based involved a need to make sales pitch in form of a presentation to a client within a few days. This client was already used to the corrupt ways of doing business with the company and would presumably be expecting some payments as in the past. This brought to the fore the urgency of beginning to communicate externally the new character of the company while still engaged with the internal communication. All the groups agreed that it would be best for the CEO of the company to meet with the CEO of the client company to let him or her know about the reorientation of the company - its new values, vision, mission and profile and its newly embraced integrity system which would preclude doing 'business as usual'.

There was some disagreement as to whether it was ethical for the company to approach the external persons (the client) before the sales pitch or whether they should rather go to make the presentation without any previous meeting but talk to the client later on about their new image. The question raised was an interesting one - that of whether a visit by the company's CEO to the client CEO would constitute or be seen by outsiders as an attempt to unduly influence the client's decision. Averring that even an informal approach between friends could raise suspicions of underhanded behaviour, one group suggested that it would be better for the meeting, though very necessary, to take place after the sales pitch rather than before.

Particular emphasis was given by one of the groups to the importance of being ready to lose the account of the client currently being prospected if they would not do clean business, and everyone agreed on the need to offer value that would be so critical that it would win over corruption each time.

In the long run, to consolidate the company's new character and image and ensure all staff experience a buy-in and feel counted upon to drive progress even more committed, it was felt that the company should demonstrate commitment to its staff by promoting unity and bonding among them and identification with the company. For example, they could give bonuses to staff at the consummation of each deal won or they could hold celebratory cocktails to mark the end of each deal, inviting clients as well.

\section{Limitations}

The classification of the expectations into 'what' and 'how' has been loosely done by the author, since this is not the main thrust of the paper. A more rigorous classification may have required coding of the stated expectations by more than one coder in order to conclude on their fit into the 'what' and 'how' categories.

The exercise did not deal with instances of yielding to extortions, which while carrying its own negative impacts on the person(s) involved, on the company and on the country's social, moral and economic good, could be in some instances defensible.

It would have been useful to try the same system for other aspects of business ethics practice in order to know if it would be as successful in fully engaging the students in solving the issues. As it were, this was a course of only ten sessions and it was not possible to do that while still dedicating time to fulfilling their 'what' expectations - a fuller understanding of what business ethics means especially in the Nigerian context.

The paper is specific to the Nigerian context. However, as amply illustrated in a recent publication on ethics in Israel (Schwartz, 2012), context is very important to studies about business ethics education. Also, some of the ideas may apply in other emerging economies where the interplay between corruption and business ethics activity may be similar to that in Nigeria. More studies on business ethics activity in Nigeria and in such countries would further enhance the impact of business ethics education.

\section{Conclusions}

In all, the exercise contributed a great deal to advancing knowledge of how to achieve a cultural and ethical transformation in a company already involved in corrupt practices. It also left the participants with a feeling of satisfaction and achievement and a confidence that they could carry out this exercise in real life if required to. It translated into an exercise in empowerment. The jointly produced ECR blueprint is a tangible outcome that could be usefully adapted by any of them in their respective companies.

This type of action learning is suitable to the current circumstances of Nigerian managers for the teaching of business ethics, since more often than not, this is the type of company in which they work. It is relevant in an environment where people know what is wrong but do not see clearly what concrete steps they could take to right it. It effectively combats the wave of disillusionment and at the same time builds up solidarity and strength together with ideas 
that everyone can tap on for use in their organizations later on. In addition, the approach would be appropriate for a capstone course if the educator wished to incorporate business ethics as its core element (Razaki and Collier, 2011). A follow up online discussion group was instituted for and by the class in order to foster and promote such interaction.

\section{References}

Heller, N. A., \& Heller, V. L. (2011). Business Ethics Education: Are Business Schools Teaching to the AACSB Ethics Education Task Force Recommendations? International Journal of Business and Social Science, 2(20), 30-39.

Jewe, R. D. (2008). Do Business Ethics Courses Work? The Effectiveness of Business Ethics Education: An Empirical Study, Journal of Global Business Issues, 2(1), 1-6.

Jones, C. A. (2005). Wisdom Paradigms for the Enhancement of Ethical and Profitable Business Practices, Journal of Business Ethics, $57(4), 363-375$.

Lau, C. L. L. (2010). A Step Forward: Ethics Education Matters! Journal of Business Ethics, 92, 565-584.

MacLagan, P. (2003). Varieties of Moral Issue and Dilemma: A Framework for the Analysis of Case Material in Business Ethics Education, Journal of Business Ethics, 48(1): 21-32.

Razaki, K. A. \& Collier, E. (2011). Ethics: the Soul of a Business Capstone Course, Journal of Academic \& Business Ethics, 5, 1-13.

Schwartz, M. S. (2012). The State of Business Ethics in Israel: A Light Unto the Nations? Journal of Business Ethics, 105, 429-446.

Appendix: Students' expectations from the business ethics course

\begin{tabular}{|c|c|c|c|}
\hline \multicolumn{2}{|c|}{ 'What' expectations } & \multicolumn{2}{|c|}{ 'How' expectations } \\
\hline & $\begin{array}{l}\text { An enhanced understanding of what business ethics } \\
\text { is. }\end{array}$ & 1. & $\begin{array}{l}\text { How best to achieve set company and individual goals without cutting corners. } \\
\text { How to be profitable even while being fair to everyone concerned. }\end{array}$ \\
\hline 2. & $\begin{array}{l}\text { Reinforcement of conviction that business ethics is } \\
\text { practicable in a corrupt environment. }\end{array}$ & 3. & $\begin{array}{l}\text { A comprehensive insight into how Nigerian companies practice business ethics. } \\
\text { How to handle ethics especially in the Nigerian context. }\end{array}$ \\
\hline 3. & $\begin{array}{l}\text { Strength to practice business ethics and inculcate it in } \\
\text { subordinates and colleagues. }\end{array}$ & $\begin{array}{l}5 . \\
6 .\end{array}$ & $\begin{array}{l}\text { How to deal with corruption that affects business success. } \\
\text { How to lead a change program. }\end{array}$ \\
\hline 4. & What are the norms of modern corporate ethics? & 7. & How to get it done in my organization. \\
\hline 5. & What constitutes unethical practices? & 8. & How to create, lead and change others from the current "Nigerian factor" syndrome \\
\hline 6. & $\begin{array}{l}\text { What is acceptable fair behaviour for a man in public } \\
\text { office or in a position of trust? }\end{array}$ & 9. & $\begin{array}{l}\text { of doing or running business in Nigeria. } \\
\text { How to inculcate business ethics principles in my organization and beyond. }\end{array}$ \\
\hline 7. & An emphasis on the need for personal integrity. & 10. & How to do business ethically. \\
\hline 8. & $\begin{array}{l}\text { Encouragement to always stand for the right even if } \\
\text { alone. }\end{array}$ & $\begin{array}{l}11 . \\
12 .\end{array}$ & $\begin{array}{l}\text { How to handle challenges that seem to call for ethical practices. } \\
\text { How to make ethical decisions that will benefit me and my organisation. }\end{array}$ \\
\hline 9. & What constitutes unethical business decisions? & 13. & How to tackle problems that arise in the realm of ethics. \\
\hline 10. & $\begin{array}{l}\text { What constitutes a breach of ethics among those } \\
\text { things that appear normal in our daily business } \\
\text { transactions? }\end{array}$ & $\begin{array}{l}14 . \\
15 .\end{array}$ & $\begin{array}{l}\text { How to act ethically in this region of the world. } \\
\text { Going beyond definitions of unethical practices to how to combat this in our } \\
\text { country. }\end{array}$ \\
\hline $\begin{array}{l}11 . \\
12 .\end{array}$ & $\begin{array}{l}\text { What is business ethics? } \\
\text { What constitutes business ethics for those in positions }\end{array}$ & 16. & $\begin{array}{l}\text { How to establish best practices and attain international standards in business } \\
\text { ethics. }\end{array}$ \\
\hline 13. & $\begin{array}{l}\text { of authority? } \\
\text { What are the ethical issues in my scope of operation? }\end{array}$ & 17. & $\begin{array}{l}\text { How to draw a line between taking advantage of opportunities and exploiting undue } \\
\text { information. }\end{array}$ \\
\hline 14. & $\begin{array}{l}\text { What are the safe alternatives when it is difficult to } \\
\text { adhere strictly to business ethics? }\end{array}$ & $\begin{array}{l}18 . \\
19 .\end{array}$ & $\begin{array}{l}\text { How to conduct business activities in the right and acceptable way. } \\
\text { How to practice ethics in personal life. }\end{array}$ \\
\hline 15. & $\begin{array}{l}\text { What are the significance of and the pivotal role } \\
\text { played by business ethics in our corporate world and } \\
\text { environment? }\end{array}$ & $\begin{array}{l}20 . \\
21 . \\
22 .\end{array}$ & $\begin{array}{l}\text { How to be a better person in critical managerial decision-making. } \\
\text { How to take and bear risks. } \\
\text { How to put ethical considerations into business in the Nigerian context. }\end{array}$ \\
\hline 16. & $\begin{array}{l}\text { What is unethical in our business and work } \\
\text { environment? } \\
\text { What is business ethics? }\end{array}$ & $\begin{array}{l}23 . \\
24 .\end{array}$ & $\begin{array}{l}\text { How do others in practice business ethics? } \\
\text { How to draw up an operational code of good conduct for my subordinates and to } \\
\text { promote it. }\end{array}$ \\
\hline 18. & $\begin{array}{l}\text { What is generally accepted or not, with regard to } \\
\text { managing loopholes, taking opportunities, declaring } \\
\text { the same? }\end{array}$ & $\begin{array}{l}25 . \\
26 .\end{array}$ & $\begin{array}{l}\text { How to decide when confronted with different problems related to business ethics. } \\
\text { How to ensure that my personal integrity stays intact, as a business manager, no } \\
\text { matter the situation. }\end{array}$ \\
\hline 19. & A clear definition of what is business ethics in general. & 27. & How to detect and avoid relationships that can crystallize into conflicts of interest. \\
\hline 20. & An enhanced ethical decision-making process. & 28. & How is business ethics practiced? \\
\hline 21. & Improved awareness of unethical situations. & 29. & How to resolve complex ethical issues in the business environment. \\
\hline 22. & $\begin{array}{l}\text { To be convinced that there are ethical ways of doing } \\
\text { things. }\end{array}$ & 30. & $\begin{array}{l}\text { How my classmate handle real life ethical issues. } \\
\text { How to do business within acceptable standards }\end{array}$ \\
\hline & Learning as much as I can about business ethics. & & $\begin{array}{l}\text { governance without losing out on profit. } \\
\text { Ethical issues people face on the job and challenges businesses have to deal with } \\
\text { and how best to handle them. }\end{array}$ \\
\hline
\end{tabular}

